\title{
SUDUT PANDANG HUKUM ISLAM DAN POSITIF \\ DALAM MELIHAT KASUS PROSTITUSI DAN HUBUNGAN SEKS DI LUAR NIKAH
}

\author{
Syarif Hidayatullah \\ Institut Agama Islam (IAI) Muhammadiyah Bima \\ Jl. Anggrek No. 16 Ranggo Na'e Kota Bima \\ ink.syarif@gmail.com
}

\section{Abstrak}

Kasus-kasus yang terjadi di masyarakat terutama terkait prostitusi serta hubungan seks bebas sangatlah meresahkan dan membuat persoalan ini menjadi sorotan yang tajam dalam kaca mata hukum, terutama dalam perspektif hukum Islam dan positif yang memang sama-sama melarang akan perbuatan tersebut namun terdapat perbedaan sanksi dan pemenuhan delik hukum yang cukup berbeda dalam melihat terutama kasus terkait hubungan seks di luar nikah yang dalam hukum Islam hal tersebut dianggap sudah terpenuhi perbuatan tersebut apabila pasangan tersebut terbukti telah melakukan hubungan di luar pernikahan baik berstatus belum menikah ataupun menikah, sebaliknya perspektif hukum positif hanya memahami bagi orang yang sudah berstatus perkawinan, dan juga persoalan dalam melihat konteks kasus prostitusi dalam sudut pandang hukum Islam dan Positif.

Keyword : Sudut Pandang, Hukum Islam, Hukum Positif, Prostitusi, Hubungan Seks di Luar Nikah. 


\section{Pendahuluan}

Hukum merupakan alat yang digunakan dalam mengontrol proses kehidupan masyarakat guna menjaga dan melindungi hakhak setiap individu dalam kehidupannya, perbuatan-perbuatan melawan hukum merupakan perbuatan yang menurut kategori hukum melanggar ketentuan yang telah ditetapkan dan berimbas pada pemberian sanksi baik berupa hukuman penjara, pembayaran denda, dan kurungan. Praktek prostitusi yang terjadi sangat membahayakan terutama terkait moral, agama dan hukum yang memang hal tersebut dilarang dan diberikan sanksi berupa hukuman, namun berbeda hal dengan perbuatan yang dilakukan secara suka sama suka yang dilakukan di luar pernikahan, yang hal itu bagi keadaan sekarang juga mengalami peningkatan dan kemerosotan etika dan moral akan pentingnya menjaga kehormatan dan diri dari perbuatan zina atau hubungan di luar nikah yang memang hal itu dilarang baik dalam konteks agama begitupun dengan norma kesusilaan, akan tetapi hubungan di luar nikah tidak dijerat ke dalam hukum kecuali salah satu pasangan tersebut berstatus suami orang atau istri orang lain yang menurut hukum sah maka baru dapat dipidanakan.

\section{A. Perspektif Hukum Islam Dalam Melihat Hubungan seks di Luar Pernikahan dan Prostitusi}

1. Hubungan di Luar Pernikahan dalam Pandangan Hukum Islam a. Konsep Hukum Hubungan seks di Luar Pernikahan (Zina)

Hubungan seks di luar pernikahan atau Zina dianggap sebagai hubungan seksual yang dilakukan oleh seorang laki-laki dengan seorang perempuan yang tidak terikat dalam perkawinan yang sah secara syariah Islam, 
dengan dasar suka sama suka dari kedua belah pihak, tanpa keraguan dari pelaku atau para pelaku zina bersangkutan. ${ }^{1}$ Dalam Islam hubungan seks di luar nikah ini dimaknai sebagai perbuatan jarimah yang mengandung hukum dan sanksi sesuai dengan hukum syara' yang tertera jelas dalam Qur'an maupun hadits yang menjelaskan tentang jarimah tersebut. Konsep hukum ini tidak lain sebagai cara dalam melindungi seseorang dari perbuatan dosa yang mana hukumnya telah ditentukan agar terhindar dan mau bertobat agar tidak lagi melakukan perbuatan tersebut. Penting bagi Islam dalam mengajarkan agar seseorang terhindar dari hal tersebut dengan dianjurkannya untuk menikah sebagai jalan pemutus atas perbuatan tersebut guna terhindar dari sanksi jarimah zina.

b. Dasar Hukum Larangan Perzinahan

Dalam konsep hukum Islam, tindakan yang berupa hubungan seks di luar pernikahan sangatlah dilarang dikarenakan pelarangan ini agar manusia tidak melewati batas seperti pada zaman jahiliyah yang memang memandang rendah seorang wanita dan dijadikan sebuah warisan, selain itu kekaburan nasab menjadi poin penting, karena keturunan akan tidak dapat diketahui jika seorang wanita disetubuhi oleh beberapa orang, dan juga hal itu juga dilarang dalam Islam, oleh sebab itu pelarangan akan zina sangatlah keras dalam Islam, sebagaimana dalam firman Allah:

${ }_{1}$ Neng; Djubaedah, Perzinaan dalam Peraturan Perundang-Undangan di Indonesia Ditinjau dari Hukum Islam (Kencana, 2010).

Sangaji Jurnal Pemikiran Syariah dan Hukum 


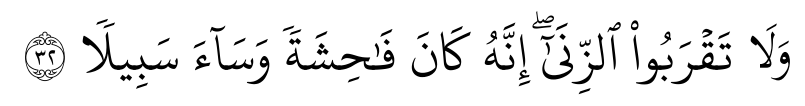

Terjemahannya:

Dan janganlah kamu mendekati zina; sesungguhnya zina itu adalah suatu perbuatan yang keji. Dan suatu jalan yang buruk. (QS al-Isra' [17]: 32) ${ }^{2}$

c. Pembagian kategori zina

Zina sendiri dalam pengkategoriannya, dalam hal ini dalam hukuman had zina, dibagi dalam dua kategori, dimana dalam konsep pidana Islam membedakan juga dari segi sanksi bagi seseorang melakukan zina yang mana bagi perjaka maupun sudah menikah memiliki kriteria berbeda dalam pemberian hukumannya, yakni:

1) Muhsan

Zina muhsan ialah zina yang pelakunya berstatus suami, istri, duda, atau janda. Artinya pelaku adalah orang yang masih dalam status pernikahan atau pernah menikah secara sah. ${ }^{3}$ Adapun sanksi yang didapatnya yakni sanksi berupa rajam, namun tidak secara eksplisit disebutkan di dalam Al Qur'an, akan tetapi penerapan hukumnya diterapkan melalui ucapan dan perbuatan Rasulullah. Selain itu ketentuannya ditetapkan di dalam hadis, ijma' para sahabat, dan pemikiran ulama fiqh dari kalangan mazhab mana pun. ${ }^{4}$ Rajam dapat didefinisikan

2 Departemen Agama RI, Terjemahan \& Tafsir Al-Qur'an Huruf Arab $\mathcal{E}$ Latin (Bandung: Fa. Sumatra, 1976).

${ }^{3}$ M. Nurul Irfan and Masyrofah, Figh Jinayah (Jakarta: Amzah, 2013).

${ }^{4}$ Ibid. 
sebagai hukuman berupa lemparan batu kecil kepada pelaku zina baik seseorang tersebut laki-laki ataupun perempuan tanpa terkecuali sampai mati.

2) Ghairu Muhsan

Zina ghairul muhsan ialah zina yang pelakunya masih berstatus perjaka atau gadis. Artinya, pelakunya belum pernah menikah secara sah dan tidak sedang berada dalam ikatan pernikahan. ${ }^{5}$ Sedangkan sanksi bagi ghairul muhsan yakni di dera. Had dera sendiri diberikan bagi pelakunya masih berstatus masih perjaka atau gadis.

Adapun had terhadap ghairu muhsan, berdasarkan surah An-Nuur [24] ayat 2, maka hukuman bagi seseorang yang dikategorikan ghairu muhsan yakni 100 kali didera di hadapan orang banyak, menurut pendapat Syafi'i dan Ahmad Ibn Hambal, di samping itu ia harus diasingkan selama satu tahun. ${ }^{6}$

2. Prostitusi Perspektif Hukum Islam

a. Konsep Hukum Prostitusi

Persoalan kesusilaan sangatlah berkaitan erat dengan keadaan sosial dan kontrol masyarakat dalam mengatasi persoalan di tengah masyarakat yang ada, karena berkaitan erat pada persoalan individu yang naik menjadi ranah sosial masyarakat yang mengandung banyak kepentingan publik yang dijaga. Islam sendiri dalam

${ }^{5}$ Ibid.

${ }^{6}$ Zainuddin Ali, Hukum Pidana Islam (Jakarta: Sinar Grafika, 2007).

Sangaji Jurnal Pemikiran Syariah dan Hukum 
mengatasi persoalan ini sangatlah berhati-hati dikarenakan selama jika hukum tersebut sudah tertuang dalam Qur'an sebagai petunjuk maka hal itu dianggap benar dan harus dilakukan, begitupun dalam Sunnah ataupun pendapat para ulama-ulama fiqh dalam mengkaji konsep hukum tersebut guna menjadi landasan pemikiran dalam memberikan jawaban atas persoalan kesusilaan yang terjadi di tengah-tengah masyarakat saat ini.

Dalam persoalan prostitusi terdapat tiga komponen penting yakni PSK, Mucikari atau Germo, dan Pelanggan, yang mana komponen ini saling berkaitan dan keterbutuhan satu sama lain. Perbuatan prostitusi ini dianggap sebagai perbuatan yang tercela dan termasuk dalam dosa besar, yang mana dalam Islam larangan berbuat zina itu dilarang, mendekati zina saja itu sudah dilarang sebagaimana dalam Qur'an Surah al-Isra ayat 32 sangat jelas Allah melarang untuk mendekati karena dianggap perbuatan mengandung perbuatan yang keji dan buruk.

Selain itu larangan dalam memperkerjakan seseorang untuk jasa tersebut dan menjadi perantara atau mucikari dalam Islam hal itu dilarang dan haram dan konsekwensinya sanksi Dosa dan ta'zir menjadi hukuman yang akan didapatkan oleh pelaku tersebut, berdasarkan surah an-Nur ayat 33:

“...dan janganlah kamu paksa budak-budak wanitamu untuk melakukan pelacuran, sedang mereka sendiri mengingini kesucian, karena kamu hendak mencari keuntungan duniawi. Dan barangsiapa yang memaksa mereka, maka sesungguhnya Allah adalah Maha 
Pengampun lagi Maha Penyayang (kepada mereka) sesudah mereka dipaksa itu."7

Pelarangan melakukan pekerjaan ini diawali utnuk dianjurkan untuk menikah, namun apabila diantara kalian tidak mampu untuk menikah maka dianjurkan untuk menjaga kesucian diri, semua itu mengarahkan seseorang untuk menikah guna menjaga diri dari perbuatan zina ataupun perbuatan yang mengandung sesusilaan terutama prostitusi yang memang sangat merusak dan merendahkan status dari kaum perempuan yang memang dianggap lemah.

B. Perspektif Hukum Positif Dalam Melihat Hubungan seks di Luar Pernikahan dan Prostitusi

1. Hubungan Seks Di Luar Nikah Hukum Positif di Indonesia

a. Konsep Hukum dan Sanksi terhadap Perbuatan hubungan seks di Luar Pernikahan (Zina) Menurut KUHP (Kitab Undang-undang Hukum Pidana)

Perspektif Hukum yang berlaku di Indonesia terutama terkait perbuatan pidana dalam landasan hukumnya terhadap kejahatan kesusilaan terkait zina, dijabarkan dan tertuang dalam beberapa pasal dan bab tertentu, yakni:

\section{Pasal 2848}

(1) Diancam dengan pidana penjara paling lama 9 bulan:

1. a. Seorang pria yang telah kawin yang melakukan mukah (overspel), padahal

${ }^{7}$ Terjemahan \& Tafsir Al-Qur'an Huruf Arab \& Latin.

8 Moeljatno, KUHP (Kitab Undang-Undang Hukum Pidana) (Jakarta: Bumi Aksara, 2021).

Sangaji Jurnal Pemikiran Syariah dan Hukum 
diketahui bahwa Pasal 27 BW berlaku baginya;

b. Seorang wanita yang telah kawin yang melakukan mukah;

2 a Seorang pria yang turut serta melakukan perbuatan itu, padahal diketahuinya bahwa yang turut bersalah telah kawin;

b. seorang wanita yang telah kawin yang turut serta melakukan perbuatan itu, padahal diketahui olehnya bahwa yang turut bersalah telah kawin dan Pasal 27 BW berlaku baginya.

(2) Tidak dilakukan penuntutan melainkan atas pengaduan suami/istri yang tercemar, dan bilamana bagi mereka berlaku Pasal $17 \mathrm{BW}$, dalam tenggang waktu tiga bulan diikuti dengan permintaan bercerai atau pisah meja dan ranjang karena alasan itu.

(3) Terhadap pengaduan itu tidak berlaku Pasal 72, Pasal 73, dan Pasal 75.

(4) Pengaduan dapat ditarik kembali selama pemeriksaan dalam sidang pengadilan belum dimulai.

(5) Jika bagi suami istri berlaku Pasal 27 BW, pengaduan tidak diindahkan selama perkawinan belum diputuskan karena perceraian atau sebelum putusan yang menyatakan pisah meja dan ranjang menjadi tetap. 
Adapun unsur dan delik tindak pidana zina, antara lain: ${ }^{9}$

a) Pria dan Wanita, yakni dalam perbuatan zina, zina dilakukan secara "bersama-sama", tidak dilakukan oleh satu orang atau dua orang yang sejenis artinya tidak dapat dilakukan antara pria dengan pria atau wanita dengan wanita;

b) Mengetahui lawan jenis terikat perkawinan, kata "mengetahui" merupakan unsur dolus (sengaja). Jika tidak mengetahui maka yang bersangkutan tidak dapat dituntut;

c) Melakukan persetubuhan;

d) Adanya pengaduan, maksudnya yakni, dalam pengaduan tidak dapat dilakukan orang lain selain suami/istri dan yang berzina itu. Pengaduan dapat diartikan sebagai keberatan dalam arti "ketidaksetujuan". Jika telah dianggap ada "persetujuan" maka tidak memenuhi syarat untuk di tuntut.

2. Prostitusi Menurut Hukum Positif di Indonesia

a. Pengertian Prostitusi

Penjabaran definisi prostitusi dianggap sebagai sebuah kegiatan yang di dalamnya terdapat wanita yang dipekerjakan oleh mucikari untuk memberikan jasa seks terhadap kaum laki-laki. atau prostitusi merupakan sebuah

9 Leden Marpaung, Kejahatan Terhadap Kesusilaan Dan Masalah Prevensinya (Sinar Grafika, 2004).

Sangaji Jurnal Pemikiran Syariah dan Hukum 
pekerjaan yang dilakukan oleh wanita yang memiliki ketrampilan rendah untuk mendapatkan gaji yang tinggi. ${ }^{10}$

b. Konsep Hukum dan Sanksi Hukum

Pada prinsipnya norma-norma sosial sudah jelas mengharamkan keberadaan prostitusi, bahkan telah diatur pula di dalam peraturan perundang-undangan mengenai praktek prostitusi yang ditinjau dari segi yuridis yang terdapat dalam KUHP yaitu mereka yang menyediakan sarana tempat persetubuhan (pasal 296 KUHP), mereka yang mencarikan pelanggan bagi pelacur (pasal 506 KUHP), dan mereka yang menjual perempuan dan laki-laki di bawah umur untuk dijadikan pelacur (pasal 297 KUHP). ${ }^{11}$

Dalam dunia kesehatan juga menunjukkan akan bahaya penyakit kelamin yang mengerikan seperti HIV / AIDS akibat hubungan bebas baik dari seks di luar nikah maupun pelacuran yang di tengah masyarakat sekarang. Meski demikian, perbuatan prostitusi masih tetap ada, bahkan terorganisir secara profesional dan rapi, tempattempat prostitusi terkadang disediakan, dilindungi oleh hukum bahkan mendapatkan fasilitas-fasilitas tertentu. Untuk itu, maka sudah seharusnya pemerintah lebih serius

10 Suhar Nanik, Sanggar Kamto, and Yayuk Yuliati, "Fenomena Keberadaan Prostitusi Dalam Pandangan Feminisme," Wacana Journal of Social and Humanity Studies 15, no. 4 (2012): 23-29.

11 SH Cok. Istri Anom Pemayun, "UPAYA PEMERINTAH DALAM MEMBERANTAS PROSTITUSI" (December 2016), accessed November 22, 2021, http://erepo.unud.ac.id/id/eprint/10246/.

Volume 5, Nomor 2, Oktober 2021 
dalam menangani permasalahan prostitusi yang menjadi penyakit masyarakat ini. ${ }^{12}$

\section{Perbedaan Konsep Sanksi}

Konsep sanksi yang diberikan baik perspektif Hukum Islam maupun hukum positif, yang mana tetap menitikberatkan pada upaya dalam mencegah dan menindak perbuatan tersebut, meskipun dalam konteks agama dan negara sangat berbeda, dari segi agama memberikan 2 (dua) keadaan hukuman yakni bersifat fisik dan dosa, sedangkan dalam konteks hukum positif memberikan keadaan hukum yakni berupa fisik (penjara, kurungan) dan ditambah denda.

Hukum Pidana di Indonesia melarang segala bentuk kegiatan dengan melacurkan orang lain dan mendapatkan keuntungan atau menjadikan sebagai mata pencaharian. ${ }^{13}$ Jadi selama orang lain tersebut mengandung mendapatkan keuntungan dari perbuatan tersebut maka dianggap telah memenuhi delik atas tindak pidana prostitusi.

Dalam hukum pidana Indonesia terkait perbuatan asusila ini terdapat keadaan dalam terpenuhinya delik nya, yakni sebuah perbuatan tidak termasuk dalam prostitusi apabila PSK (pekerja seks komersial) dengan pelanggannya secara diri sendiri atau mengelolanya sendiri, maka hal tersebut bukanlah tindak pidana menurut KUHP Indonesia, sehingga segala bentuk kegiatan prostitusi yang dikelola atau di-manage

12 Ibid.

${ }^{13}$ Ahmad Sofian, "PROSTITUSI ONLINE DALAM HUKUM PIDANA INDONESIA," Business Law, last modified January 2019, accessed November 22, 2021, https://business-law.binus.ac.id/2019/01/15/prostitusi-online-dalamhukum-pidana-indonesia/.

Sangaji Jurnal Pemikiran Syariah dan Hukum 
sendiri oleh dirinya dengan pelanggannya tidak bisa dikategorikan sebagai delik yang diancam dengan hukuman termasuk juga pelacuran online yang dikelolanya sendiri dengan pelanggan/pelanggan-pelanggannya. ${ }^{14}$

Hal ini dikarenakan dalam Undang-undang Informasi dan Transaksi Elektronik (ITE) yakni dalam Undang-undang Nomor 11 Tahun 2008 pun tidak memberikan ancaman pidana atas sebuah tindakan pelacuran online yang dikelola oleh si prostitusi kepada pelanggan-pelangganya. Pasal 27 ayat (1) UU ITE memberikan ancaman hanya pada perbuatan yang mendistribusikan, mentransmisikan, atau membuat dapat diaksesnya informasi elektronik yang melanggar kesusilaan. Informasi elektronik yang melanggar kesusilaan menurut tafsir dari ilmuwan hukum pidana diantaranya adalah berupa gambar, video, percakapan, animasi, sketsa yang mengandung konten kecabulan, persetubuhan, kekerasan seksual, alat kelamin. Objek perbuatan kesusilaan ini pun harus disebarluaskan ke publik melalui media elektronik (email, media sosial, atau layanan pesan singkat). Mengacu pada ketentuan UU-ITE, jika perbuatan yang dilakukan berisi pesan untuk melacurkan dirinya tetapi tidak disebarluaskan ke publik maka tidak memenuhi unsur dari pasal 27 ayat (1) UU-ITE. ${ }^{15}$

Begitupun persoalan mempersoalkan pelanggan yang membeli seks pada sebuah kegiatan prostitusi. Hal ini menunjukkan bahwa pembeli seks pada sebuah kegiatan prostitusi bukanlah sebuah delik atau perbuatan yang melawan

14 Ibid.

15 Ibid. 
hukum, kecuali jika yang dibeli adalah anak-anak yang belum berusia 18 tahun. Jika hal ini dilakukkan, maka dalam konsep Hukum Pidana maka perbuatan ini bisa diancam dengan UU Perlindungan Anak (UU No. 23 Tahun 2002 Juncto UU No. 35 tahun 2014). Demikian juga jika pembeli seks adalah laki-laki atau perempuan yang telah bersuami/beristeri maka bisa dikenakan delik zina sebagaimana diatur dalam Pasal 284 KUHP dengan ancaman pidana maksimum 9 bulan. Namun delik zina ini adalah delik aduan, sehingga harus ada pengaduan dari pasangan yang syah yaitu suami atau isteri pelaku zina. Jika tidak ada pengaduan, maka pembeli seks tersebut tidak dapat dikatakan melakukan tindak pidana sebagaimana diatur dalam Pasal 284 KUHP. ${ }^{16}$

Sebaliknya dalam Islam perbuatan melacurkan diri ataupun berbuat zina semua itu mendapatkan sanksi tanpa terkecuali baik itu dengan usaha sendiri dalam memberikan jasa seks ataupun dengan perantara begitupun perbuatan seks di luar nikah, karena sudah sangat jelas dalam konsep hukum Islam keadaan tersebut dan perbuatan tersebut dilarang dan sanksi had atas jarimah tersebut sangatlah jelas baik dalam Qur'an maupun dalam Sunnah dan pendapat para ulamaulama Fiqh.

\section{Keadaan Sosial dan Reaksi Hukum}

Keadaan sosial sekarang terutama dalam mengkontrol perilaku remaja mulai terasa sulit, hal ini terjadi dari berbagai faktor, faktor-faktor tersebut bisa dikarenakan, proteksi orang

16 Ibid.

Sangaji Jurnal Pemikiran Syariah dan Hukum 
tua yang kurang, lingkungan yang buruk, teman sejawat yang memang sudah berkecimpung dengan hal tersebut, masyarakat yang mulai acuh tak acuh dengan keadaan sekitar, lebih penting yakni tentang pendidikan agama yang sangat kurang dikalangan remaja sekarang, menjadikannya tingkat kasus hamil di luar nikah menjadi tinggi dan perilaku seks bebas yang kian lama tidak bisa terkontrol, dalam Islam pendidikan agama terutama menjadi diri dari hal tersebut sangatlah diutamakan terlebih karena perbuatan zina ataupun prostitusi sangat merusak diri sendiri maupun orang tua dan keluarga, karena memelihara agama dan jiwa menjadikan salah satu alasan dalam menjaga diri dari perbuatan maksiat, terlebih sudah jelas bagaimana konsekwensi dari perbuatan tersebut akan mendapatkan sanksi baik jarimah had dera ataupun rajam bagi seseorang yang telah melakukan hubungan seks di luar nikah.

Konsekuensi dari perkembangan seksual remaja kerapkali berkembang ke arah yang negatif berupa perilaku seksual maupun prostitusi. Seks yang dulu disakralkan bagi anak-anak remaja, kini demikian terbuka bahkan menjadi kebiasaan (trend) dan gaya hidup (lifestyle). Pada tahun 2008, Survey Komnas Perlindungan Anak di 33 Propinsi menyimpulkan bahwa 97\% remaja SMP dan SMA pernah menonton film porno, 93,7\% remaja SMP dan SMA pernah melakukan genital stimulation (meraba alat kelamin) dan oral seks, 62,7\% remaja SMP dan SMA tidak perawan dan 21,2\% remaja mengaku pernah aborsi. Data Pusat Keluarga Berencana Indonesia (PKBI) pada tahun 2006 menunjukkan bahwa kisaran umur melakukan hubungan seks pranikah pada usia 13-18 
tahun. ${ }^{17}$ Ironis bagi kita dengan melihat keadaan remaja yang sudah diambang kemerosotan ini, maka dari itu diperlukan upaya pencegahan yang kongkrit dari seluruh elemen masyarakat, pendidikan dan aparat dalam memahami kasus dan persoalan ini dengan bijak, baik edukasi akan seks, pendidikan agama yang intens dan upaya kontrol masyarakat dan keluarga dalam mengawasi pergaulan yang berlebihan.

Selain tindakan perbuatan seks di luar pernikahan, problematik sosial yang masih marak di tengah masyarakat adalah prostitusi, dalam sebuah penelitian disebutkan bahwa ada keadaan dan bermacam-macam motif seorang wanita terjun dalam praktek prostitusi diantaranya: ${ }^{18}$

1 Tekanan ekonomi, faktor kemiskinan, ada pertimbanganpertimbangan ekonomis untuk mempertahankan kelangsungan hidupnya, khususnya dalam usaha mendapatkan status sosial yang lebih baik;

2 Keinginan materi yang tinggi pada diri wanita dan kesenangan ketamakan terhadap pakaian-pakaian yang indah dan perhiasan mewah. Ingin hidup bermewahmewahan, namun malas bekerja;

3 Anak-anak wanita yang memberontak terhadap otoritas orang tua yang menekankan banyak tabu dan peraturan seks;

4 Oleh bujuk rayu kaum pria dan para calo terutama yang menjanjikan pekerjaan-pekerjaan terhormat dengan gaji

17 Lutfi Irwansyah, "Kemiskinan, Keluarga Dan Prostitusi Pada Remaja," Psychology and Humanity 2 (2016): 19-20.

18 Syafruddin, "Prostitusi Sebagai Penyakit Sosial dan Problematika Penegakan Hukum" (June 5, 2002), accessed November 21, 2021, https://repository.usu.ac.id/handle/123456789/1550.

Sangaji Jurnal Pemikiran Syariah dan Hukum 
tinggi, namun kenyataannya ia hanya dicebloskan ke dalam rumah bordil;

5 Gadis-gadis pelayan toko dan pembantu rumah tangga tunduk dan patuh melayani kebutuhan seks majikan demi mempertahankan pekerjaannya;

6 Pekerjaan sebagai pelacur tidak memerlukan keterampilan, mudah dikerjakan asal orang yang bersangkutan memiliki kecantikan, dan keberanian;

7 Anak-anak gadis dan wanita muda yang kecanduan obatobat terlarang sehingga mereka akan melakukan apa saja untuk mendapatkan obat-obat tersebut termasuk melakukan pelacuran.

Selain itu juga, masih maraknya kasus prostitusi antara lain disebabkan: ${ }^{19}$

1 Adanya keinginan dan kemauan manusia untuk menyalurkan kebutuhan seks khususnya di luar ikatan perkawinan,

2 Merosotnya norma-norma susila dan keagamaan pada saatsaat orang mengenyam kesejahteraan hidup,

3 Kebudayaan eksploitasi pada zaman modern ini, khususnya mengeksploitir kaum lemah/ wanita untuk tujuan-tujuan komersil.

Selain itu, Prostitusi atau pelacuran merupakan penyakit masyarakat yang semakin marak sekarang ini. Namun pada jaman sekarang, prostitusi oleh masyarakat Indonesia dianggap menjadi sesuatu hal yang biasa dan hampir ada di setiap daerah, tidak hanya di kota-kota besar namun mencakup

19 Ibid. 
keseluruhan daerah terpencil sekalipun. ${ }^{20}$ Dari keadaan ini saja dapat memberikan kita pandangan bagaimana kasus asusila dan norma-norma hukum yang ada di tengah masyarakat sudah mulai tergerus akibat kesadaran akan hukum dan agama sudah mulai diambang kemerosotan, dan tentu bagi negara ini menjadi point penting dalam mengatasi persoalan prostitusi sekarang, yang dulu mungkin bersifat tersembunyi sekarang sudah mulai merambat secara online, dan itu malah membuat prostitusi menjadi marak dan mudah dalam mengakses dan mencari jasa tersebut terutama bagi para hidung belang dan itu menjadi ironis bagi Indonesia.

Penegakan hukum diharapkan dapat menjadikan garda terdepan dalam mengontrol tindakan tersebut baik upaya dalam membubarkan kerumunan malam dan swiping di diskotik yang ada guna meminimalisir akan tindakan tersebut, selain itu banyak pimpinan daerah yang mengatur dan membuat aturan dalam mengatasi prostitusi dan zina yang sering terjadi di kos-kosan yang membuat masyarakat resah dalam mengontrol perilaku remaja yang sudah mulai diambang batas norma.

\section{SIMPULAN}

Dari sudut pandang antara hukum Islam dan Positif samasama memberikan sanksi bagi setiap orang yang telah melanggar hukum terkait persoalan kesusilaan terutama prostitusi yang memang bersifat terorganisir dan saling mencari keuntungan

20 Cok. Istri Anom Pemayun, "UPAYA PEMERINTAH DALAM MEMBERANTAS PROSTITUSI."

Sangaji Jurnal Pemikiran Syariah dan Hukum 
dengan jalan yang batil dan haram, akan tetapi terdapat perbedaan sudut pandang bahwa hukum Islam dalam melihat tindakan jarimah zina atau hubungan seks di Luar Nikah dan prostitusi dianggap perbuatan yang haram, baik itu dilakukan dengan diri sendiri dan suka sama suka tetap akan dikenakan sanksi atas perbuatan tersebut karena tidak ada unsur yang menggugurkan atau peniadaan seseorang tersebut tidak mendapatkan dosa dan had atas jarimah ataupun dikenakan $t a^{\prime} z$ ir atas perbuatan tersebut.

Sedangkan dalam hukum positif, dalam memahami pemenuhan delik jika perbuatan hubungan seks di luar nikah dilakukan dengan suka sama suka maka hal tersebut tidak dikenakan hukum terutama bagi yang pasangan masih berstatus perjaka dan perawan, begitupun juga konteks prostitusi jika dilakukan oleh diri sendiri dan tidak disebarluaskan di publik maka tidak dapat dikenakan delik atas tindakan pidana prostitusi dan zina, namun lain halnya jika berstatus telah menikah dan disebarluaskan di publik maka delik atas kedua tindakan pidana tersebut terpenuhi.

Dari perbedaan konsep inilah yang membuat masyarakat secara tidak langsung memberikan dan menetapkan hukum secara spesialis dalam lingkupnya dengan berbagai hasil hukum dan perspektif yang berbeda dalam mengatasi persoalan ini, karena tidak tercovernya tindakan bagi yang masih jejaka yang memang hal itu menjadi persoalan tingginya kasus seks bebas dan hamil di luar nikah yang dianggap sangat mencoreng masyarakat dan keluarga. 


\section{DAFTAR PUSTAKA}

Ali, Zainuddin. Hukum Pidana Islam. Jakarta: Sinar Grafika, 2007.

Cok. Istri Anom Pemayun, SH. “UPAYA PEMERINTAH DALAM MEMBERANTAS PROSTITUSI" (December 2016). Accessed November 22, 2021. http://erepo.unud.ac.id/id/eprint/10246/.

Departemen Agama RI. Terjemahan \& Tafsir Al-Qur'an Huruf Arab $\mathcal{E}$ Latin. Bandung: Fa. Sumatra, 1976.

Djubaedah, Neng; Perzinaan dalam Peraturan Perundang-Undangan di Indonesia Ditinjau dari Hukum Islam. Kencana, 2010.

Irfan, M. Nurul, and Masyrofah. Fiqh Jinayah. Jakarta: Amzah, 2013.

Irwansyah, Lutfi. "Kemiskinan, Keluarga Dan Prostitusi Pada Remaja." Psychology and Humanity 2 (2016): 19-20.

Marpaung, Leden. Kejahatan Terhadap Kesusilaan Dan Masalah Prevensinya. Sinar Grafika, 2004.

Moeljatno. KUHP (Kitab Undang-Undang Hukum Pidana). Jakarta: Bumi Aksara, 2021.

Nanik, Suhar, Sanggar Kamto, and Yayuk Yuliati. "Fenomena Keberadaan Prostitusi Dalam Pandangan Feminisme." Wacana Journal of Social and Humanity Studies 15, no. 4 (2012): 23-29.

Sofian, Ahmad. "PROSTITUSI ONLINE DALAM HUKUM PIDANA INDONESIA." Business Law. Last modified January 2019. Accessed November 22, 2021. https://businesslaw.binus.ac.id/2019/01/15/prostitusi-online-dalam-hukumpidana-indonesia/.

Sangaji Jurnal Pemikiran Syariah dan Hukum 
Syafruddin. "Prostitusi Sebagai Penyakit Sosial dan Problematika Penegakan Hukum" (June 5, 2002). Accessed November 21, 2021. https://repository.usu.ac.id/handle/123456789/1550. 